\title{
LITERÁRNII VĚDA A KULTURNÍ DĚDICTVÍ V PRAGMATICKÝCH SOUVISLOSTECH. K ODKAZU PETRA LIBY ${ }^{1}$
}

\author{
Literary Criticism and Cultural Heritage in Pragmatic Contexts. \\ On the Legacy of Peter Liba
}

\author{
Anna Zelenková - Alexej Mikulášek
}

DOI: 10.17846/CL.2021.14.1.167-176

\begin{abstract}
ZELENKOVÁ, Anna - MIKULÁŠEK, Alexej. Literary Criticism and Cultural Heritage in Pragmatic Contexts. On the Legacy of Peter Liba. The study evaluates the methodological contribution of a Slovak literary scholar Peter Liba (1931 - 2020), who was one of the founders of the Institute for Research of Constantine and Methodius' Cultural Heritage and the University of Constantine the Philosopher in Nitra. As a literary scholar, Liba significantly influenced the theory of interpretation and communication in a number of humanistic fields of study and thematic areas (folklore, popular literature, translation, children's and youth literature, bibliography, biography studies, textology, culturology etc.). The study also defines the researcher's autonomous position within the so-called semiotic-communication Nitra school and its expressive theory of the text, which the work of aforementioned professor enriched interdisciplinary with diachronic and comparative aspects of not only primary but also secondary communication. Within its framework, Liba elaborated on the problems of the functions of literary education, typology of reading and literacy, literary-museum communication, biography studies and circulation of the so-called degraded layers of literary development. As a literary theorist, he came from textological analysis and heuristic research to uncovering the connections between literature and culture and its ethical dimension.
\end{abstract}

Keywords: Peter Liba, Nitra school, Slovak literary criticism, communication theory, culturology, Institute for Research of Constantine and Methodius' Cultural Heritage

\begin{abstract}
„Nesumarizujeme [...], naopak otvárame problémy“ (Liba 1987, 11), charakterizoval svou literárněvědnou metodu v úvodu ke své monografii Čitatel' a literárny proces (Bratislava, 1987) slovenský literární vědec a kulturolog Peter Liba (1931 - 2020), který výrazně zasáhl do řady oblastí literatury a kultury. Spř́zněnost, ale i jistá autonomie v rámci nitranské, sémioticko-komunikační školy, předznamenala jeho vklad nejen do slovenského, ale i českého myšlení o literatuře, který se projevil v kritickém dialogu s dobou, v hledání a kladení nových otázek, akcentujících „čítanie v súvislostiach a čítanie pod povrchom textu“ (Liba 2009b, 47). Liba patřil ke skupině intelektuálně vlivných badatelů rozvíjejících především teorii literární komunikace v návaznosti na potřeby literárněvědné, literárněkritické, ediční a pedagogické praxe. Tito badatelé inovativně rozpracovali komplexní teorii interpretace, recepční žánrovou poetiku, teorii a historii literatury pro děti a mládež
\end{abstract}

1 Část A. Zelenkové je výstupem v rámci vědeckého projektu APVV-19-0244 Metodologické postupy v literárnovednom výskume s presahom do mediálneho prostredia. Hlavní řešitel prof. PhDr. Ján Gbúr, CSc. Doba řešení: 2020 - 2024. 
(s ohledem na tzv. dětský aspekt), vytvořili ucelenou teorii překladu ad., a to nikoli bez nutných kontaktů se zahraničím, jak je připomněla mj. Mária Valentová (Valentová 2017). Ona „nitrianska literárnovedná škola“ se rozvíjela na půdě Vysoké školy pedagogické v Nitře v rámci Kabinetu literární komunikace a experimentální metodiky, oficiálně založeného k 1. 1. 1969 z iniciativy jeho pozdějších kolegů, jakými byli František Miko, Anton Popovič a Ján Kopál (Žilka 2015, 11). Liba, ačkoli formálně přišel z Martina do Nitry roku 1973 na katedru slovenské literatury, byl s tímto Kabinetem spojen relativně jednotnou a formovanou terminologií, systematickým a komplexně systemizujícím myšlením, zájmem o komunikační rozměr literárních jevů a s ním související intertextualitu, dnes přerůstající v moderní intermedialitu.

Podle Žilky nitranská škola, která se záhy stala fenoménem evropské úrovně, mj. kriticky navázala na výzkumy českých badatelů, jakými byli např. Jan Mukařovský, Frank Wollman, Jiří Levý, Sáva Šabouk, Ivo Osolsobě nebo Zdeněk Mathauser (Žilka 2006, 163). Inspirativní práce nitranských literárních vědců nacházely pro své novátorství uplatněné při analýze literárních textů ohlas i v zahraničí. Tato škola, kam se právem zařazoval od počátku sedmdesátých let i Peter Liba, „popri inakosti jednotlivcov i ich pracovného štýlu“ (Žilka 2006, 163) vytvořila respektovanou institucionální bázi pro výzkum literárního textu, kterou od samého začátku sjednocoval zájem o pragmatický aspekt sémiotiky, o vztah text - čtenář (Žilka 2006, 162). S tímto zaměřením se identifikoval i Liba, jehož př́nos spočíval v tom, že výrazovou teorii textu integroval do oblasti literárního vzdělávání a jeho funkcí (Liba 1978), otázek biografistiky (Liba 1976) a literárněmuzejní problematiky (Popovič - Liba - Kopál 1977). Celkově tak interdisciplinárně obohatil poznání primární i sekundární komunikace o komparativní aspekty při zachování sémioticko-recepčního rámce (srov. Zelenková 2011). „Mohli sme rozpálení čítat literatúry zo Západu a tým sme sa skôr napojili na existujúci európsky prúd, čím žila vtedy literárna veda“ (Liba 1999, 162), vzpomínal s odstupem času Liba, jehož publikační činnost $\mathrm{z}$ tohoto hlediska zřetelně svědčila o falešnosti představy, že československá literární věda po druhé světové válce se ocitla „v zajetí železné opony“ izolována od „velkého světa“ a jeho koncepcí, jež jsou dnes vcelku standardně součástí výkladů literárněvědných směrů a metodologií druhé poloviny 20. století. Zapomíná se ovšem, že i v relativně nepříznivých podmínkách existovala ohniska samostatného a inovativního vědeckého myšlení v zemích tzv. východního bloku (J. M. Lotman a tartusko-moskevská škola, M. Bachtin, G. Lukács, I. Sőtér, J. Sławiński, D. S. Lichačov, H. Markiewicz a mnoho dalších), že si silné osobnosti dokázaly najít cesty $\mathrm{k}$ čilé zahraniční spolupráci navzdory byrokratickým a cenzurním omezením. Týká se to např. teorie literární a umělecké komunikace a v jejím rámci např. komplexně interpretace uměleckého textu nebo teorie překladu, spojované s osobností Antona Popoviče, nebo výrazová teorie textu a stylu Františka Mika, rovněž literární komparatistiky a v jejím rámci pak tzv. zvláštních meziliterárních společenství Dionýze Ďurišina; na české straně pak jmenujme např. teorii ediční činnosti a praktickou textologii (Rudolf Havel a kol.) nebo translatologii (Jiří Levý, Karel Horálek ad.).

Nahlédnutí do vědecké i osobní biografie Petra Liby jasně vypovídá o jeho rozsáhlé vědecké, pedagogické, kulturní a společenské činnosti, která byla oceněna řadou cen a vyznamenání. Jak připomíná v souvislosti s jeho vysokoškolským učitelským působením Silvia Lauková: „Jeho myslenie [...] bolo vždy interdisciplinárne, kontextové a otvorené pre nové výzvy modernej spoločnosti“ (Lauková 2020). Pokud bychom chtěli - aspoň stručně - naznačit jednotlivé tematické okruhy Libova literárněvědného zájmu, na prvním místě by bylo nutné připomenout jeho zásluhy o rozvoj slovenské teorie i praxe bibliografie i biografie; v letech 1968 - 1971 působil jako ředitel Bibliografického ústavu Matice slovenské a jeho zkušenosti se projevily v monografii Bibliografia $v$ procese (Martin, 2006), přinášející studie a prŕspěvky z teorie a dějin slovenské bibliografie. V studii Osoba - biografia - literárna komunikácia (Liba 2009a) v rámci metodologických zásad nitranské školy upřednostňuje sémantiku před sémiotikou, význam před obrazností. Literární dílo 
proto pro něho zůstává vždy neuzavřenou jedinečnou výpovědí, kterou přijímáme a recipujeme jako specifickou duchovní skutečnost. Diskuse o kořenech Libovy metodologie, které se údajně odrazily v jeho snaze o vědeckou exaktnost, v pragmatizaci uvažování a v sestavování binárních opozicí, nejsou z tohoto hlediska důležité, a proto lze souhlasit $s$ tvrzením, že badatel „[...] má sklon teoretizovat’ a systemizovat' len tol'ko, kolko si to vyžaduje riešenie jeho bádatel'ského záujmu a pragmatika kultúrnej situácie“ (Marčok 2002, 49). Jako autor a spoluautor se podílel na mnoha badatelských i učebních projektech, z nichž můžeme připomenout kvalitní vysokoškolskou učebnici Interpretácia umeleckého textu (Bratislava, 1981) ve spolupráci s Antonem Popovičem, Petrem Zajacem a Tiborem Žilkou, dodnes metodologicky i jinak užitečnou ve své části teoretické i v praktických interpretacích vybraných děl slovenské literatury.

Právě v Interpretácii umeleckého textu se projevila Libova úcta k textu, která souvisela se zřejmým respektem k historickému materiálu - sám začínal svou vědeckou dráhu v biografickém oddělení Matice slovenské v Martině a v jeho literárněvědné metodě sehrává výraznou úlohu aspekt literární biografie a antropologického př́stupu. Pro něho je důležité vidět za textem i konkrétního autora, pochopit jeho důvody, proč vlastně píše. Odlišnost od klasické interpretační metody spočívá $\mathrm{v}$ tom, že bere více do úvahy moment tradice, jehož prostřednictvím se nekomunikuje jen s literární minulostí, ale i s budoucností. Dodnes zůstává nedostatečně doceněným momentem v Libově vědeckém profilu zásadní podíl na založení známé edice Literárny archív v roce 1964, v níž se publikovaly výsledky vědecké práce v Matici slovenské, a tím se dostávaly do širšího česko-slovenského výzkumného kontextu a čtenářského povědomí. Vydávání archivních textů přispívalo podle něho $\mathrm{k}$ realizaci modelu literární komunikace a k axiologickému překonání symbolické „vzdálenosti“ mezi autorem a čtenářem (Liba 1964a). Zejména čtenářské potřeby jsou určujícím prvkem v recepci a percepci textu a ovlivňují jeho interpretaci.

Čtenářské potřeby hrály důležitou úlohu i v Libových názorech na textologii a editorskou praxi. V nich nejde jen o mechanické stanovení redakčních úprav, ale o postupné odkrývání hodnot a vrstvení významů $\mathrm{v}$ procese psaní a čtenářské recepce, celkově o dotváření smyslu textu. Literárním dílem se totiž Liba zabýval na pozadí společenských a kulturních konvencí, zajímalo ho textové i mimotextové „dění smyslu“, pohyb a stálost v autorském záměru a čtenářských konkretizacích. V prvním ročníku edice Literárny archív 1964 recenzoval vydaný soubor vzájemných listů Jaroslava Vlčka a Jozefa Škultétyho, který vyzdvihl nejen jako biografický dokument, ale zejména jako „klíćc k hlubšímu pochopení velkých osobností slovenské kultury, o nichž napsal, že jejich korespondence se pro svou recepční přitažlivost „dá čítat ako beletria“ (Liba 1964b, 238). V následujícím roce ve sborníku Literárny archív 1965 zhodnotil stav slovenské textologie a stanovil dodnes obecně platné zásady pro vydávání literárních textů (Liba 1965). Velmi cenné jsou z tohoto hlediska rovněž jeho textologické studie, z nichž jmenujme např. $O$ (ne-) užitočnosti reprodukcie textu (Textologická prolegomena folklóru) (Liba 2000a) nebo O účelovom prepise textov (Liba 2000b) či Pragmatické editovanie (editorstvo) ludovej rozprávky (Liba 1996). Před autentickou podobou textu zde Liba upřednostnil zásadu publikovat rukopisy v konečném znění se všemi původními opravami a zásahy jako přirozený výsledek komunikačního procesu, který se přizpůsobuje autorovi a kontextu jeho díla. Odmítal proto striktní dodržení principů nejen tzv. diplomatického vydání, ale i tzv. popularizačního vydávání. Podle něho „vydávaný text sa má priblížit dnešnému čitatelovi v takej podobe, aby sa neporušil pôvodný text natolkko, aby ho z prepísaného textu, na základe prepisových zásad, nebolo možné zrekonštruovat" (Liba 1965, 204). Z oboru teorie kultury můžeme jmenovat např. jeho monografie Dostredivé priestory literatúry (Nitra, 1995), Otvorené návraty (Nitra, 2001), Kultúra/literatúra (Nitra, 2005) a Prieniky do literatúry a kultúry (Nitra, 2009) (srov. Zelenková 2010). Jejich společným prvkem, charakteristickým pro Libovy texty z posledního dvacetiletí, se stává oscilace mezi ergocentrickým a kulturologickým chápáním literární vědy. Jde v nich zejména o odkrývání souvislostí mezi literaturou a kulturou, s čím souvisí i nový 
prvek - tematicko-metodologické zaměření na duchovní prostor literatury. Tento posun se výrazně odráží v jeho intelektuálních úvahách o současné, přelomové situaci člověka a slovenské kultury v dnešním „chaosu bezbřehého postmodernismu“ a globálního světa. Je tu charakteristické prolnutí tří aspektů - literárněteoretického, komunikačně-sémiotického a pedagogického -, které se odehrává $\mathrm{v}$ dialogu, $\mathrm{v}$ němž autor upřednostňuje zážitkový př́stup před racionálním hodnocením. Viditelné je to zejména $\mathrm{v}$ jeho výroku, že pouze $\mathrm{v}$ „porozumení sa rozohrá zážitkový a obohacujúci proces rozdávania a prijímania básnických hodnôt" (Liba 2009b, 36), a proto vyslovuje otázky, v nichž se zamýšlí nad změnou dnešního žebřričku hodnot, tudíž nad změnou současného vývoje literatury. Tyto otázky vedou $\mathrm{k}$ návratu $\mathrm{k}$ původnímu poslání psaného slova, a právě to dokáže podle Liby napomoci $k$ „otevřenému čtení. Jde mu především o odkrývání nových, někdy navenek i marginálních a nedoceňovaných stránek literární historiografie. Např́klad zvažuje otázku křestanského pohledu na literaturu, který se předtím nemohl rozvíjet, ale přesto působil při formování slovenské identity. V úvodním slovu k monografii Otvorené návraty se Liba přiznává $\mathrm{k}$ heideggerovským podnětům „prestahovat’ sa do svojich vlastných počiatkov“, tzn. realizovat otevřené sondy „do tých vrstiev slovenskej literatúry a kultúry, ktoré odkazujú na zakladajúce, trvalé, oživujúce hodnoty“ (Liba 2001, 5). A jestliže spolu s tím tvrdí, že „všetky texty literárnej a kultúrnej minulosti sú vždy v pozícii otvorenej ponuky, v pozícii aktualizovaného príjmu“ (Liba 2001, 5), je zde určitá inspirace gadamerovskou hermeneutikou a barthesovským chápáním „nulového stupně rukopisu“. Podle autora jsou texty navzdory své kanonizované struktuře „př́stupné“ novým interpretacím, které nejvíce ovlivňuje čtenář svými potřebami.

Podle Liby nabízí text určitou recepční výpověd', která závisí od struktury textu a čtenářských schopností, ale zároveň před čtenáři něco skrývá. Badatel upozorňuje na „slepá“ místa v struktuře literárního díla, jež jsou otevřená dalším konkretizacím. Připomíná, že literární historik by měl být skromným zprostředkovatelem, vytvářejícím ze souboru faktů, dějů a procesů obrysy jedinečných, ale zevšeobecňujících lidských „příběhư“. Posláním literárního vědce proto není př́ímočaré dešifrování autorského záměru a jeho kódu, ale zprostředkování sémantických možností textu, které jsou sice „otevřené“, ale ne bez hranic. Typické pro Libu bylo i to, že ho v posledním období zajímalo zejména fungování textu v kultuře, schopnost díla recepčně oslovit co nejširší okruh čtenářu a jeho schopnost napomáhat literárnímu vývoji. Interpretace textu tak přechází do úvah o lidské dimenzi kultury a o ontologické podstatě individuálního a kolektivního bytí. Liba si uvědomoval, společně se spisovateli a umělci, o nichž psal, že „knihy majú svoje osudy len práve z ohladu na čitatela“', a to někdy dokonce „osudy nezávislé od autora, alebo aj protikladné úmyslu samého tvorcu“ (Liba 1992, 143). Přitom viděl jistou autonomii uměleckých a estetických hodnot, které mohou být $\mathrm{v}$ čtenářských konkretizacích různě aktualizovány a přirozeně i interpretovány. Zřetel ke čtenáři je $\mathrm{v}$ jeho badatelské i kritické a esejistické činnosti všudypř́ítomný a netýká se jen analýzy děl populárního písemnictví. Spojuje se v něm vědomí kooperace autora a čtenáře, autorského předjímání čtenářových očekávání, rozbor technik a metod jejich naplňování, hodnocení kvality.

„Text nie je ešte literárnym dielom, ním sa stáva v komunikácii“ (Liba 1987, 45), napsal v mikovské linii chápání textu a podle něho je třeba za literaturu bojovat, obhajovat ji, vysvětlovat samotný text může demonstrovat svou „uměleckost“ i přes zanedbávanou výchovnou funkci spojenou s aspektem morálky a křest̉anství. Liba proto své dialogy rozvíjí především recepčně př́stupnou formou, kde jeho vlastní myšlenkový svět splývá s citově podmaněným světem adresáta (Obert 1999, 210). Ideální dialog si tudíž vyžaduje v politice, ale i v kultuře nevyhnutelnost komunikace, schopnost poslouchat a porozumět. Dialog mezi literaturou a kulturou je podle něho zároveň výrazem zodpovědnosti $k$ člověku, ochranou před mocí a manipulací. Uvědomuje si, že literární vědec neustále srovnává a vybírá z řady možností, ale vždy se musí dobrat názoru autora na pozadí dobové recepce. Interpretačně-sémiotické možnosti textu však neznamenají 
neomezenou svobodu slova. V eseji Hodnotový filter kultúry, která uzavírá monografii Prieniky do literatúry a kultúry, traktuje současnou krizi kultury jako spor mezi estetikou a racionálností, jako spor vědy a víry, a proto krize civilizace vystupuje v Libových textech jako krize slova: „[...] podstata krízy kultúry je vždy vyjadrením neusporiadanej slobody a nezriadenej lásky“ (Liba 2009b, 283).

Liba si prošel různými etapami vědecké kreativity a v posledním dvacetiletí se profiloval především jako křestanský intelektuál, kde důležitou stránkou jeho myšlení o roli tradice v historii slovenské kultury se stala koncepce historismu jako tematizovaného vědomí umělce o historických událostech a jejich interpretaci. Mnoho úvah a studií věnoval představitelům slovenské katolické literatury, zvláště Jánu Chryzostomu Korcovi, ale i Pavlu Straussovi či Rudolfu Dilongovi. V řadě př́spěvků, jako lektor-recenzent i autor kritických posudků a studií, se zajímal o otázky biblických žalmů z hlediska genologického a jejich transformačních adaptací (Liba 2001a, 9-40), také o ruskou náboženskou filozofii a duchovní slovesnou kulturu, např. o dílo Vladimíra Sergejeviče Solovjova (Liba 2001b), rovněž o církevní (církevně slovanskou) kulturu a její kontinuitu (Liba 2004a). Už jako děkan Pedagogické fakulty v roce 1991 považoval za „ústretový program“ této vzdělávací instituce zápas o zřízení Univerzity sv. Cyrila a Metoda (Liba 1999, 39). Jeho pozdější inaugurace jako prvního rektora Univerzity Konštantína Filozofa v Nitře 13. 2. 1997 se symbolicky konala v předvečer výročí smrti svatého Cyrila. V slavnostním „príhovoru“ se vědomě přihlásil k cyrilometodějské tradici jako ke kulturně-duchovní misi soluňských bratrů, poskytující „klič k poznáni““ všem, kteří o to požádají a kteří se chtějí vzdělávat v rodném jazyce (Liba 1999, 51-54). Cyrilometodějskou tradici ve vývoji slovanské kultury a literatury Liba posuzoval nejen historickou, ale i aktualizační optikou, v níž se uplatnila např̀. hlediska křestanského univerzalismu, národně emancipačního ideálu či náboženské tolerance. Pro badatele totiž nebyl fenomén vlastenectví v rozporu s univerzalistickými nároky moderního člověka. Po skončení všech oficiálních akademických funkcí Liba počátkem 21. století na cyrilometodějskou tradici nezapomněl. Jako hlavní iniciátor stál u zř́zení Ústavu pre výskum kultúrneho dedičstva Konštantína a Metoda oficiálně existujícího od listopadu 2007 při Filozofické fakultě UKF jako centrálního badatelského a dokumentačního pracoviště, které si klade za cíl v interdisciplinárním kontextu zkoumat axiologické a kulturně-duchovní aspekty byzantské mise a její celoevropské tradice.

Právě Nitra se podle Liby stává jako jedno z center Velké Moravy místem, kde se formuje a později nejzřetelněji projevuje kulturní odkaz byzantské mise. Koncepce církevněslovanského jazyka jako slovesného nástroje esteticky vyspělého básnictví - a v tom badatel navazuje na výzkumy českého byzantologa Františka Dvorníka či světoznámého slavisty Romana Jakobsona - vytváří předpoklady pro jazykově-etnickou diferenciaci Slovanů a tím i pro „první formulaci národní myšlenky v [...] celých slovanských dějinách“ (Jakobson 1996, 12). Pozdější násilné přerušení cirkevněslovanské kultury proto bylo tragickým zlomem, který charakterizuje i slovenské dějiny. Liba není klasický filolog paleoslavistické orientace ani specializovaný historik-medievalista a jeho př́stup k cyrilometodějské tradici je spíše pohledem slovensky cítícího, patrioticky orientovaného kulturologa a křestanského antropologa, který Konstantinův Proglas a životopisnou a legendistickou literaturu Velké Moravy analyzuje z hlediska jejího př́nosu pro duchovní linii slovenského písemnictví (Liba 2003), protože tyto texty přecházejí „hranicami časov“ a jsou „súčastou nás samých, našej kultury, nášho myslenia [...]“ (Liba 2012, 7). Projevilo se to i ve výběrových antologiích Svätý Cyril a svätý Metod v slovenskej literatúre (Nitra, 2012) a Medzi trvaním a dějinami. Cyril a Metod v slovenskej literatúre (Nitra, 2013), kde v spolupráci se Silvií Laukovou shromáždil cenný materiál zpřítomňující „stopu“ cyrilometodějské mise a její uchování v původní slovenské spisbě.

Důležitou oblastí Libova zájmu, ne vždy doceňovanou, byla translatologie, jakkoli aplikovaná v historicko-komunikační perspektivě. Např. společně s Antonem Popovičem, Františkem Mikem, Tiborem Žilkou, Jánem Kopálem a dalšími přispěl do výkladového slovníku translatologických 
pojmů Originál - preklad. Interpretačná terminológia (Bratislava, 1983), koncepčně však vedeného Popovičem. Podnětnou studií nazvanou Kultúra a preklad (Liba 2004b) rovněž obohatil sborník Preklad a kultúra (Nitra, 2004) apod. Jeho zájem o obecnou teorii překladu byl domněle jen př́ležitostný, analýza překladů a adaptací však konstantně doprovázela jeho trvalý zájem interdisciplinární, spojující literární historii, folkloristiku (Liba 1991) a teorii kultury s potřebou pragmatického, zejména terminologického, vymezení. Překlad v této souvislosti ve své translatologické praxi vztáhl zejména na recepční fungování v oblasti populární literatury, kde rozpracoval problematiku explicitních indikátorů překladovosti a její typologie (překlad volný, reprodukční, kontaminovaný, zprostředkovaný, podveršový, modelový apod.) a kde vymezil dva hodnotové póly - překlad jako transfer a absence překladu ve vědomí překladu (Liba 1980). Podle Liby slovenskou teorii překladu, která čerpá z literární komparatistiky Dionýze Ďurišina a ze sémioticko-komunikační koncepce Antona Popoviče, charakterizuje paradox nepoměru mezi primárním a sekundárním literárním oběhem, tj. fenomén převahy sekundární reprodukce nad primární produkcí. Tento paradox však nesvědčí o zaostalosti či nerozvinutosti malých národních kultur, protože ty „zo svojej bytostnej povahy rozvíjajú prekladovost' ako rovnocennú tvorivú spisovatel’skú činnost“ (Liba 2001, 165).

Tento výzkum se soustředil především do oblasti teorie a historie populární literatury, zejména slovenské, jejíž výzkumy, vedle českých badatelů jako Jan Cigánek (srov. jeho Umění detektivky, 1962 a Úvod do sociologie umění, 1972) nebo Josef Hrabák (srov. Napinavá četba pod lupou, 1986 a Od laciného optimismu $k$ hororu, 1989), rozvíjel či přímo inicioval. Týká se to především monografie Kontexty populárnej literatúry (Bratislava, 1981), která demonstrovala jeho celoživotní zájem o tzv. literární subkulturu, o problematizaci vztahu centra a periferie. Systematicky přistupoval k zábavné a konzumní četbě, do které na rozdíl od českých teoretiků jako Oldřich Sirovátka, Josef Hrabák, Karel Horálek ad. zahrnoval i formy nebeletristické, věcné, jako jsou snáře, proroctví, kalendáře apod., akcentoval axiologicky i esteticky „pokleslé“ vrstvy literatury. Liba zdůrazňuje především funkčně komunikační povahu populární literatury, její ohled na specifické čtenářské potřeby a očekávání, i na komplex funkcí, které plní. Populární literaturu nechápe jen jako okraj umělecké literatury stojící hodnotově v opozici k ní, ale také jako samostatné centrum literární kultury s vlastní axiologickou výbavou a realizací, v níž se uplatňuje funkční modifikace slovesnosti umělé, resp. umělecké, nejednou i slovesnosti folklórní a produkce užitkové, pragmatické. $\mathrm{Na}$ této bázi analyzuje prrítomnost čtenáře a jeho kompetence $\mathrm{v}$ komunikační perspektivě textu, všímá si rovněž recepčních stereotypů, jež mají v této kulturní oblasti klíčovou pozici, konturuje jeho komunikační kapacity a zkušenostní komplex; za samožrejmost pokládá autorovy projekce čtenářských očekávání a stereotypů (mentálních i slovesných), jež jsou do sledované skupiny textů zakódovány.

Libův trvalý zájem o praktickou i teoretickou translatologii potvrzuje i kapitola šestá nazvaná Preklad populárnej literatúry (Liba 1981, 156-174), sledující i adaptace a úpravy v komunikační perspektivě překladu. Jak je pro badatele prŕznačné, stranou nenechává ani teorii a historii tzv. dětské literatury, konkrétně popularizační aspekty v naučné literatuře pro děti. Osobitě se např. zaměřoval na tvorbu Jozefa Nižňanského v kontextu populární kultury meziválečného období. Např̀. v souvislosti s recepcí české populární literatury zaznamenává „dve základne situácie [...] priamu a sprostredkovanú prekladmi. Pre prvú nemáme priame doklady (bežný čitatel' nezanecháva stopy po sformulovanej lektúre). Máme však dostatok dôkazov o tejto českej lektúre v odsudzujúcej kultúrnej, školskej kritike, uverejňovanej v oficiálnych časopisoch, v autobiografických dokumentoch spisovatelov, redaktorov a iných. Pre druhú situáciu poskytuje bibliografia medzivojnovej knižnej produkcie dôkaz o vyše 45 populárnych knižných edíciach [...]. Ukazuje sa, že práve priama, neevidovatel’ná čitatel’ská komunikácia českej populárnej literatúry vykonala zretel’nejší vplyv na rozvoj slovenskej populárnej literatúry“ (Liba 1981, 214-215). Z hlediska 
vymezení pojmu je důležitý Libův důraz na funkční synkretismus a na vymezení role estetické funkce v textu: „Populárnu literatúru z hladiska funkčných zložiek charakterizuje teda oslabovanie diferenciačných funkcií, čo sa prejavuje v spomínanom funkčnom synkretizme a v tom, že sa estetická funkcia nestráca, ibaže [...] neovplyvňuje celkový výraz diela. [...] Populárna literatúra vykazuje tedy funkčné kombinácie nezávislé od estetickej funkcie, pravda nikdy nie na nulovom stupni, pretože ani v populárnej literatúre nedochádza k jej úplnej likvidácii, totiž k strate ,literárnosti““ (Liba 1981, 33).

Pro analýzu žánrově tematické oblasti definovatelné volně jako „literatura pro mládež a lid“ je mimořádně cenná faktograficky, materiálově fundovaná monografie Čítanie starých otcov (Martin, 1970), ve které píše o přirozeném spojování „výchovnej funkcie pre mládež a dospelých v prozaickej literatúre určenej pre lud“ (Liba 1970, 87), k němuž přirozeně a běžně docházelo i v prostoru slovesnosti původem sice německé, ale do českého a slovenského prostředí včleňované jazykovými adaptačními strategiemi. V této souvislosti analyzuje recepci tvorby Ch. v. Schmida, K. G. Nieritze a F. Hoffmanna a jejich adaptace v slovenském kulturním areálu. Tím doceňuje i domněle okrajové žánry literatury pro děti a mládež, jakými byly žánry mravoučné beletrie, především mravoučná povídka, přičemž tyto povídky se kromě „zdôraznenej pedagogickej tendencie vyznačujú [...] tým, že hlavnými postavami sa stávajú predovšetkým deti: statočné, múdre, nábožné, obdarené vlastnostami, ktoré sú im v živote na užitok“ (Liba 1970, 88). Podle autora tyto povídky byly závislé na „námetových a kompozičných klišé romantickej sentimentálnej poviedky“ (Liba 1970, 88). Už v této monografii se pokusil na základě rozsáhlého empirického výzkumu o vymezení komunikačního modelu populární literatury, která funguje nejen jako „okraj“ či „periferie“, ale i jako samostatné centrum, jako autochtonní složka literární kultury. V tomto druhém pojetí je estetická funkce plnohodnotně sublimována do čtyř specifických funkcí jako přístupnost, zábavnost, senzibilita a poučnost (didaktičnost), které tvoří hodnotový základ masově šírené komunikace.

Své názory na výzkum vzájemných souvislostí umělé literatury a folklorních artefaktů a tradic nejzřetelněji vyjádřil ve své monografii Literatúra a folklór (Nitra, 1991) (srov. Mikulášek - Zelenka 1992). Autorovi zde nejde o tradiční studium folklóru jako autochtonního kulturního fenoménu, ale o fungování folklórních jevů v literárním textu, tj. o literární folklorismus a jeho adaptační posuny. Ty komunikačně vymezuje binární opozicí lidovost x nelidovost, resp. folklorizací literatury a „zliterárněním“ slovesného folklóru (Liba 1991, 50). Mezi těmito vrstvami literární kultury existuje pulzační souvztažnost, která se od poloviny 20. století naklání ve prospěch umělého písemnictví, které „postupně s civilizačným procesom ludstva preberá mnohé funkcie slovesného folklóru“" (Liba 1991, 46). Liba tento proces demonstruje na vývoji vybraných žánrových forem, jako jsou balady, volební písně, bajky, zbojnické povídky apod. Z tohoto zorného úhlu interpretuje texty J. Cígera-Hronského, Š. Krčméryho, R. Slobody, V. Šikuly ad. Zásadní je podle našeho názoru poznatek, který zapadá do okruhu nitranské školy, tudíž, že „pre výskum recepcie folklórneho textu je dôležitý reproduktand, príjemca-producent, a nie anonymný či kolektívny autor“ (Liba 1991, 35). V tomto prŕpadě se jedná o polemiku s názory, podle nichž schopnost poskytovat čtenáři prostor k seberealizaci mohou pouze díla náročná, „Vysoká“, nikoli lidová slovesnost. I př́ijemce např. masově šířeného a charakterem „populárního“ folklorního žánru je schopen do textu projektovat své hodnotové a estetické potřeby. Důkazem toho je skutečnost, že v slovenském kontextu se „literární folklorismus“ svým psychologickým základem promítl i do původní tvorby pro děti a mládež, nebot’ spojil představivost lidového člověka a dítěte (Liba 1991, 116-117). Folklórnost se tak stává relevantním rysem i interpretačním kličem k hlubšímu porozumění četných děl slovenské dětské literatury (M. Ďuríčková, K. Jarunková, M. Rázusová-Martáková atd.).

Literárněkritický zájem věnoval mnohým představitelům současné slovenské lyriky, např. Milanu Rúfusovi, Jozefu Leikertovi (např. sborník Časy a čas; Nitra, 2010) nebo Štefanu 
Moravčíkovi, stranou nezůstali ani představitelé slovenské prózy jako Ján Lenčo, Peter Andruška, Ladislav Ťažký či Rudolf Schuster, jemuž adresoval monografii Osobné a verejné v diele Rudolfa Schustera (Bratislava, 2004). Liba pravidelně komentoval i novinky slovenské, české a překladové literární vědy, ze zahraničního myšlení o literatuře do tehdejšího kontextu (zejména v normalizačním období) uváděl základní tituly již tehdy metodologicky inovativní polské literární vědy (M. Głowiński, J. Starnawski, J. Ziomek ad.). Ta v tomto období sloužila pro řadu badatelů jako zprostředkující mezičlánek kontextu se světem. Badatel se zde neváhal např. kriticky vyrovnat s marxisticko-sociologickou koncepcí literární kultury Stefana Żolkiewského a vyzdvihl zakladatelský význam tzv. pragmatické poetiky Eugeniusze Czaplejewicze a Edwarda Kasperského (Liba 1979), kteří ve slovanském kontextu 70. let 20. stol. nezávisle na nitranské škole zformulovali dialogický model umělecké komunikace. Jako literární kritik se nevyhýbal ani kulturní publicistice, která se promítla do monografie Kultúrnost' vzdelávania (Nitra, 1999), v níž teoreticky profilovaného literárního vědce pouze navenek střídá pedagog, který utilitárně z pozice vysokých akademických funkcí (v letech 1993 - 1996 rektor Vysoké školy pedagogické a v letech 1997 - 1999 rektor nově vzniklé Univerzity Konštantína Filozofa v Nitře) sleduje otázky vzdělávání, praktické morálky a obecně kulturní politiky. V tomto souboru statí, rozhovorů a dokumentů z let 1990 1999 zřetelně vyniká autorovo úsilí vytvořit moderní univerzitu mimo hlavní centrum, a to jako plnohodnotnou nositelku vědeckovýzkumných aktivit, ale i humanistických idejí. Více než ekonomické fungování univerzity má na mysli její duchovní a axiologický rozměr, celkově otázky morálky a kulturnosti.

Při shrnující charakteristice Libovy vědecké osobnosti třeba konstatovat, že nikdy nebyl představitelem tradiční literární vědy. Navzdory tomu, že se zdánlivě mohl jevit jako konzervativní, je jeho metoda díky svým antropologickým a interkulturním aspektům moderní - interdisciplinárně se pohybuje mezi sociologií, kulturologií a teologií a nesoustředuje se pouze na klasickou interpretaci nebo běžný rozbor uměleckého díla. Jak jsme již uvedli, Libovi slouží texty $k$ tomu, aby je četl, srovnával, uvažoval o nich a v souvislosti s tím s nimi vedl „osobní dialog“. Jako křestanský intelektuál vycházel z velké úcty k psanému slovu, a proto literární dějiny neviděl jako abstraktní schémata, ale hledal za nimi konkrétní lidský příběh. Jeho rehabilitace antropologizujícího přístupu k minulosti výrazně souvisí se specifickým pojetím biografistiky, kterou považoval za součást dialogu s tradicí a pamětí dějin. Vědecká biografistika se proto podle něho musí zkoumat jako dějiny mentalit osob a nejen jako dokumentování událostí v rámci literárněhistorické metody. Vědeckou a uměleckou biografistiku vymezuje jako záměrnou kulturní aktivitu, protože všechny osoby z minulosti vstupují do kulturního povědomí prostřednictvím textů, které se projevují jako „významy“, „,hodnoty“, „symboly“ apod. Tím dovršil svou přeměnu z klasického literárního vědce na kulturologa, jenž zkoumá pamět dějin jako základ konkrétních kulturních tradic, které nám esteticky zpř́stupňují staré, avšak čtenářsky živé hodnoty. Podle Vincenta Šabíka Liba rozvíjel odvětví kulturologie, které bychom mohli pojmenovat jako „kulturu vzpomínání, chápanou jako možnost přenosu mezigeneračních vazeb minulosti s budoucností (Šabík 2002). Sám Liba svou metodu komentoval autoreflexivním výrokem: „Mojím záujmom je vždy otvárat otázky, vstupovat do nich a osvetlovat ich význam pre dalšie porozumenie“ (Liba 2009b, 12).

Čtení Libových textů otevírá dveře do duchovní sféry literatury (Valentová 2010, 75) a není didakticky jednoduché. Cesta $\mathrm{k}$ jejich pochopení vede prostřednictvím komparativního a kritického vnímání, a proto jeho texty, v dobrém slova smyslu, zůstávají náročnou lekturou. „Kladou odpor“ už ustáleným názorům a vyzývají k reflexím o individuálním a existenciálním osudu člověka. Podle Libových vlastních slov tu nejde o ricoeurovský konflikt „[...] interpretácií sveta a života“, ale jde o potřebu „[...] v prievane dejín riešit krízu súčasného človeka“ (Liba 2005, 13). 
V jedné své básni z července 2000 Ked’ nastane neodvolatelné mlčanie Liba napsal tento smutný verš: Ten môj skon, ten môj skok do neznáma / nepocíti nikto zo živých: ani polná tráva (Liba 2002, 152), který lze interpretovat jako připomínku jeho lidské i vědecké pokory.

\section{REFERENCES}

Jakobson, Roman. 1996. Cyrilometodějské studie. Praha (původně 1954. The Beginnings of National Self-Determination in Europe. In The Review of Politics 7/1).

Lauková, Silvia. 2020. Zomrel profesor Peter Liba. https://www.ff.ukf.sk/913-zomrel-profesorpeter-liba.

Liba, Peter. 1964a. Úvodom. In Literárny archív 1964. Pramene a dokumenty. Martin, 5-7.

Liba, Peter. 1964b. Vzájomné listy Jaroslava Vlčka a Jozefa Škultétyho. In Literárny archív 1964. Pramene a dokumenty. Martin, 232-238.

Liba, Peter. 1965. Zásady pre vydávanie literárnych textov v zborníku Literárny archív. In Literárny archív 1965. Pramene a dokumenty. Martin, 201-208.

Liba, Peter. 1970. Č́tanie starých otcov. Príspevok k výskumu spoločenskej funkcie a k vydávaniu prozaickej literatúry pre lud na Slovensku v rokoch 1848 - 1918. Martin.

Liba, Peter. 1976. Biografistika v systéme literárneho vzdelávania. Zborník z 2. konferencie o živote a diele P. O. Hviezdoslava v Dolnom Kubíne. Dolný Kubín - Nitra, 21-39.

Liba, Peter. 1978. Tendenčný prepis v systéme literárneho vzdelávania. Nitra.

Liba, Peter. 1979. Pragmatická poetika. In Estetika 16/4, 255-258.

Liba, Peter. 1980. Preklad populárnej literatúry. In Komparatistika a preklad. Acta Facultatis Philosophicae Universitatis Šafarikanae. Literárnovedný zborník 6. Bratislava, 169-182.

Liba, Peter. 1981. Kontexty populárnej literatúry. Bratislava.

Liba, Peter. 1987. Čitatel' a literárny proces. Bratislava.

Liba, Peter. 1991. Literatúra a folklór: Príspevok k literárnemu folklorizmu. Nitra.

Liba, Peter. 1992. Koncepcia Braneckého románu Fráter Johannes. In O interpretácii umeleckého textu 14. Nitra, 143-158.

Liba, Peter. 1996. Pragmatické editovanie (editorstvo) ludovej rozprávky. In Obert, Viliam (ed.). Žánrové hodnoty literatúry pre deti a mládež 3. Nitra, 7-18.

Liba, Peter. 1999. Kultúrnost' vzdelávania (Výber zo štúdií, príhovorov, rozhovorov a dokumentov z rokov 1990 - 1999). Nitra.

Liba, Peter. 2000a. O (ne-) užitočnosti reprodukcie textu (Textologická prolegomena folklóru). In Literatúra pre deti a mládež v procese II. Nitra, 151-177.

Liba, Peter. 2000b. O účelovom prepise textov. In Literárnovedné štúdie I. Nitra, 9-40.

Liba, Peter. 2001a. Otvorené návraty. Nitra.

Liba, Peter. 2001b. Čítajúc Vl. Solovjova. In Červeňák, Andrej (ed.). Vladimír Solovjov po sto rokoch. Nitra, 91-110.

Liba, Peter. 2002. Ked’ nastane neodvolatelné mlčanie. In Červeňák, Andrej (ed.). Život a dielo Petra Libu. Nitra, 152.

Liba, Peter. 2003. Čo znamenajú cyrilo-metodské tradície? In Červeňák, Andrej (ed.). Almanach Nitra 2003. Nitra, 34-35.

Liba, Peter. 2004a. Krestanstvo a slovenská literatúra. In Rydlo, Jozef M. (ed.). Renovatio spiritualis. Bratislava, 501-513.

Liba, Peter. 2004b. Kultúra a preklad. In Gromová, Edita (ed.). Preklad a kultúra. Nitra, 11-30.

Liba, Peter. 2005. Kultúra/Literatúra. Nitra. 
Liba, Peter. 2009a. Osoba - biografia - literárna komunikácia. In O interpretácii umeleckého textu 24. Autentické a univerzálne v tvorbe a interpretácii umenia. Nitra, 90-104.

Liba, Peter. 2009b. Prieniky do literatúry a kultúry. Nitra.

Liba, Peter - Lauková, Silvia. 2012. Slovo na úvod. In Liba, Peter - Lauková, Silvia (eds.). Svätý Cyril a svätý Metod v slovenskej literatúre. Výberová antológia. Nitra, 7-8.

Marčok, Viliam. 2002. Hodnota Libovho objavu populárnej literatúry. In Červeňák, Andrej (ed.). Život a dielo Petra Libu. Nitra, 46-64.

Mikulášek, Alexej - Zelenka, Miloš. 1992. Literatúra a folklór. In Zlatý máj 36/1, 55-57.

Obert, Viliam. 1999. Pozvanie do dialógu (o kultúre a kultúrnosti poznávania). In Liba, Peter. Kultúrnost' vzdelávania (Výber zo štúdií, príhovorov, rozhovorov a dokumentov z rokov 1990 - 1999). Nitra, 209-212.

Popovič, Anton - Liba, Peter - Kopál, Ján. 1977. Literárnomúzejná komunikácia. In Literárne múzeum v komunikácii. Zborník prác z III. konferencie o literárnomúzejných problémoch v Dolnom Kubíne 1976. Dolný Kubín - Nitra, 9-37.

Šabík, Vincent. 2002. Medzi bibliofíliou a kulturológiou. In Červeňák, Andrej (ed.). Život a dielo Petra Libu. Nitra, 77-89.

Valentová, Mária. 2010. Peter Liba. In Červeňák, Andrej. Život v literatúre. Môj album. Nitra.

Valentová, Mária. 2017. Anton Popovič a jeho nitrianská translatologická škola. In World Literature Studies 9/2, 49-60.

Zelenková, Anna. 2010. Peter Liba, Prieniky do literatúry a kultúry. In Porównania 7, 249-252.

Zelenková, Anna. 2011. Čítanie pod povrchom textu a čítanie významov. In Slovenská literatúra 58/4, 369-373.

Žilka, Tibor. 2015. Dobrodružstvo teórie tvorby. Nitra.

Žilka, Tibor. 2006. (Post)moderná literatúra a film. Nitra.

doc. PhDr. Anna Zelenková, Ph.D.

Czech Academy of Sciences, Institute of Slavonic Studies

Valentinská 1

11000 Praha 1

Czech Republic

zelenkova@slu.cas.cz

PhDr. et PaedDr. Alexej Mikulášek, PhD.

Constantine the Philosopher University in Nitra

Faculty of Central European Studies

Institute of Languages and Cultures of Central Europe

Dražovská 4

94974 Nitra

Slovakia

alexej.mikulasek@seznam.cz

ORCID ID: 0000-0001-9036-0816

WOS Researcher ID: AAE-3464-2020

SCOPUS Author ID: 57213591325 